\title{
Photoinduced Electron Transfer in Silylene-Spaced Copolymers Having Alternating Donor-Acceptor Chromophores
}

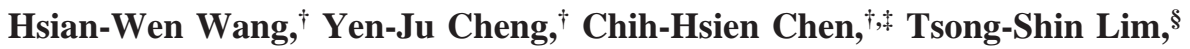 \\ Wunshain Fann, ${ }^{\S}$ Cheng-Lan Lin,,$+\star$ Yuan-Pin Chang, ${ }^{\dagger}$ Kin-Chuan Lin, ${ }^{\dagger}$ and \\ Tien-Yau Luh*,
}

\author{
Department of Chemistry, National Taiwan University, Taipei, Taiwan 106; Institute of Chemistry, \\ Academia Sinica, Taipei, Taiwan 115; and Institute of Atomic and Molecular Sciences, Academia \\ Sinica, Taipei, Taiwan 106
}

Received January 16, 2007; Revised Manuscript Received February 13, 2007

\begin{abstract}
Silylene-spaced copolymers with alternating azacrown and anthracene moieties were synthesized for photoinduced electron transfer investigations. These polymers exhibited efficient intrachain photoinduced electron transfer with charge separation yield about 0.96-0.99 and corresponding charge-transfer rates around $10.8-32.2 \mathrm{~ns}^{-1}$ in different solvents. Metal cations have been shown to enhance the fluorescence intensity due to complexation. These results are comparable to those of small molecules having similar chromophores. The geminal dimethyl substituents on silicon in these copolymers may direct the relative conformation (or distance) of the remaining substituents on silicon. Intrachain interactions between these chromophores may readily take place leading to highly efficient electron transfer processes.
\end{abstract}

\section{Introduction}

There have been ever burgeoning interests in model systems to simulate photoinduced electron transfer (PET) in photosynthesis. ${ }^{1}$ Donors and acceptors can be covalently bonded in small molecules, ${ }^{2}$ in self-assembled systems, ${ }^{3}$ in dendrimers, ${ }^{4}$ or in polymers..$^{5}$ We recently reported that silylene-spaced divinylarene copolymers $\mathbf{1}^{6}$ constituting of alternating donor and acceptor chromophores have demonstrated versatile photophysical properties such as intrachain fluorescence resonance energy transfer (FRET), ${ }^{7}$ through-space chromophore-chromophore interactions, ${ }^{8}$ and the transmission of chiroptical properties. ${ }^{9}$ The monosilylene moiety is considered as an insulating spacer, and no conjugative interactions between the $\pi$ systems and the silicon moiety may occur. ${ }^{6-10}$ The enhancement of emission from the acceptor chromophore indicates that light harvesting may take place in these regioregular silicon-containing copolymers. ${ }^{7}$ The donor and acceptor chromophores would therefore be in close proximity. The use of the silylene spacer to link donor and acceptor chromophores for electron transfer has been briefly explored. ${ }^{2 \mathrm{c}}$ It is envisaged that the photoinduced electron transfer might also occur in such silylene-spaced copolymers 1 when the donor and acceptor chromophores are regioregularly arranged. In particular, copolymer $\mathbf{1}$ can easily be accessible by hydrosilylation of the corresponding bis-alkyne and bisvinylsilanes in an alternating manner. ${ }^{6-9}$

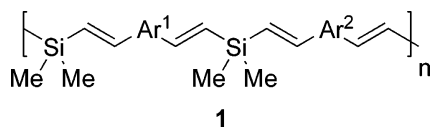

It is known that amines may quench the fluorescence of a fluorophore by means of PET. ${ }^{11,12}$ Our design involves the synthesis of silicon-containing polymers similar to $\mathbf{1}$ by incorporation of fluorophores and amine receptors in alternating

\footnotetext{
$\dagger$ National Taiwan University.

Institute of Chemistry, Academia Sinica.

$\S$ Institute of Atomic and Molecular Sciences, Academia Sinica.
}

manners separated by insulating silylene spacers. Anthracene moiety was chosen as the fluorescent probe because its photophysical properties have been well-studied, and it has been widely used for fluorescent sensing studies. ${ }^{13}$ Crown ethers are well-known for their excellent affinity toward different metal cations. ${ }^{14}$ Various fluorescent PET sensors have been made through the combination of a guest binding site and a fluorophore. ${ }^{15}$ Azacrown ethers occasionally act as the receptor for metal ions, and the nitrogen moiety acts as the donor for electron transfer. ${ }^{11}$ We now wish to report the design and synthesis of silylene-spaced alternating donor-acceptor copolymers for PETs.

\section{Results and Discussion}

Synthesis. 9,10-Bis(dimethylsilyl)anthracene (2) was prepared according to literature procedure (eq 1). ${ }^{16}$<smiles>Brc1c2ccccc2c(Br)c2ccccc12</smiles><smiles></smiles><smiles>C[Si](C)c1c2ccccc2c([SiH](C)C)c2ccccc12</smiles>

The azacrown moiety was synthesized in a manner similar to that described in the literature (Scheme 1). ${ }^{17}$ Reaction of triglycolyl chloride 3 with 4-iodoaniline afforded bisamide 4 in $82 \%$ yield. Reduction of $\mathbf{4}$ with $\mathrm{BH}_{3} \cdot \mathrm{SMe}_{2}$ gave $85 \%$ yield of diamine $\mathbf{5}$ which was allowed to react with diglycolyl chloride under high dilution conditions to furnish macrocyclic bislactam 6 in $74 \%$ yield. Simlarly, bislactam 7 was obtained in $68 \%$ yield when 3 was employed. Reduction of $\mathbf{6}$ and 7 with $\mathrm{BH}_{3} \cdot \mathrm{SMe}_{2}$ gave $\mathbf{8}$ and $\mathbf{9}$ in 71 and $82 \%$ yield, respectively. Palladiumcatalyzed Sonogashira reactions of $\mathbf{8}$ and $\mathbf{9}$ with trimethylsilylacetylene afforded 73 and $70 \%$ yield of $\mathbf{1 0}$ and $\mathbf{1 1}$, respectively. Desilylated bisalkynes $\mathbf{1 2}$ and $\mathbf{1 3}$ were obtained from the reactions of $\mathbf{1 0}$ and $\mathbf{1 1}$ in methanolic sodium hydroxide in $\mathbf{9 0 \%}$ yield each. 

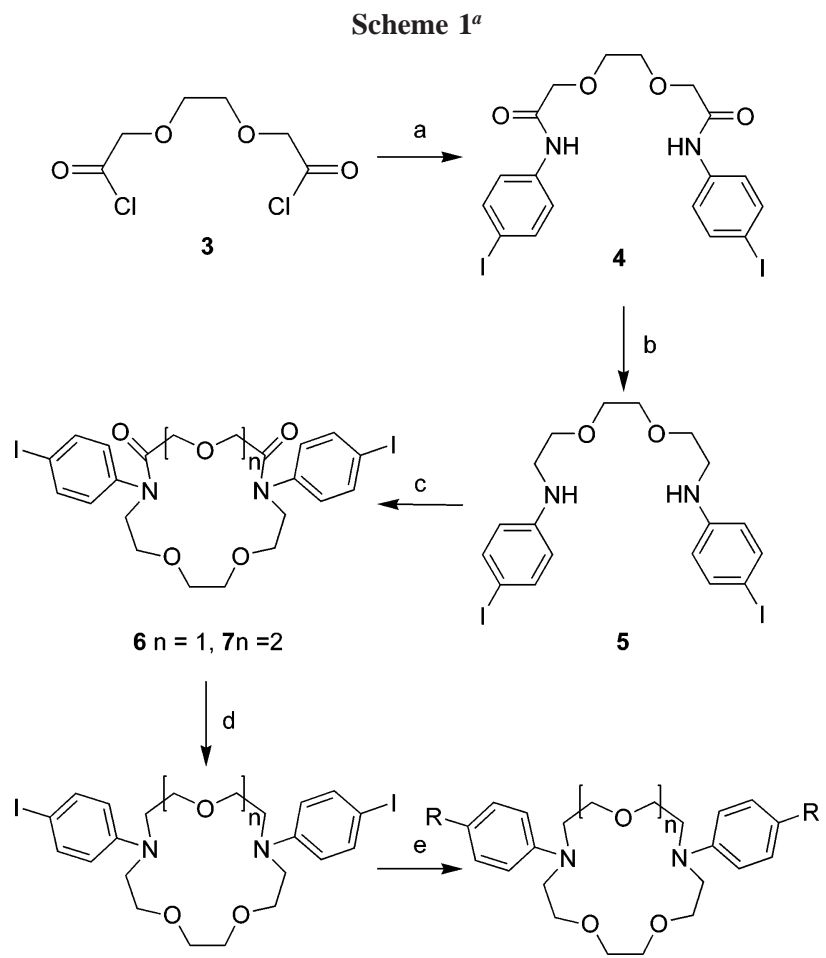

$8 n=1,9 n=2$

$$
\begin{aligned}
& \mathrm{R}=\overline{\overline{1}} \mathrm{TMS} \\
& f\left(\begin{array}{l}
10 n=1,11 n=2 \\
R=\equiv H
\end{array}\right. \\
& -12 n=1,13 n=2
\end{aligned}
$$

a Key Reagents: (a) 4-I- $\mathrm{C}_{6} \mathrm{H}_{4} \mathrm{NH}_{2}$, py, THF, rt, 2 h, 82\%; (b) $\mathrm{BH}_{3}$. $\mathrm{SMe}_{2}$, THF, reflux, $16 \mathrm{~h}, 85 \%$; (c) $\mathbf{3}$ or 3-oxagluraric dichloride, py, PhMe, rt, $12 \mathrm{~h}, 71 \%(n=1), 68 \%(n=2)$; (d) $\mathrm{BH}_{3} . \mathrm{SMe}_{2}$, THF, reflux, 16 h, 71\% ( $n=1) ; 82 \%(n=2)$; (e) TMSC $\equiv \mathrm{CH}, \mathrm{PdCl}_{2}\left(\mathrm{PPh}_{3}\right)_{2}, \mathrm{CuI}$, THF/Et 3 N (1:2), reflux, 8 h, 73\% $(n=1) ; 70 \%(n=2)$; (f) $\mathrm{NaOH}$, $\mathrm{CH}_{3} \mathrm{OH} / \mathrm{THF}(1: 1)$, rt, 1 h, $90 \%(n=1) ; 90 \%(n=2)$.

Table 1. Photophysical Properties and Frontier Orbital Energies of 2 and 16

\begin{tabular}{rclcccc}
\hline & $\begin{array}{c}\lambda_{\max \text { abs }} \\
(\mathrm{nm})\end{array}$ & $\begin{array}{c}\lambda_{\max \mathrm{em}} \\
(\mathrm{nm})\end{array}$ & $\Phi^{a}$ & $\begin{array}{c}E_{\mathrm{ox}}{ }^{b} \\
(\mathrm{~V})\end{array}$ & $\begin{array}{c}\mathrm{HOMO}^{c} \\
(\mathrm{eV})\end{array}$ & $\begin{array}{c}\mathrm{LUMO}^{d} \\
(\mathrm{eV})\end{array}$ \\
\hline $\mathbf{2}$ & 378 & 412,433 & 0.65 & 0.18 & -5.55 & -2.54 \\
$\mathbf{1 6}$ & 308 & 378 & 0.03 & 0.75 & -4.98 & -1.57
\end{tabular}

${ }^{a}$ Using coumarin-1 as a reference. ${ }^{b}$ Oxidation potentials determined by cyclic voltammetry using $0.1 \mathrm{M} \mathrm{Bu}_{4} \mathrm{NPF}_{6}$ as electrolyte with Pt working electrode, $\mathrm{Pt}$ wire as counter electrode, and $\mathrm{Ag} / \mathrm{AgNO}_{3}$ as reference electrode. ${ }^{c}$ Estimated by $E_{\mathrm{ox}} \mathrm{vs} \mathrm{Fc} / \mathrm{Fc}^{+} .{ }^{d}$ Estimated by $\mathrm{HOMO}$ and optical band gap from absorption spectra.

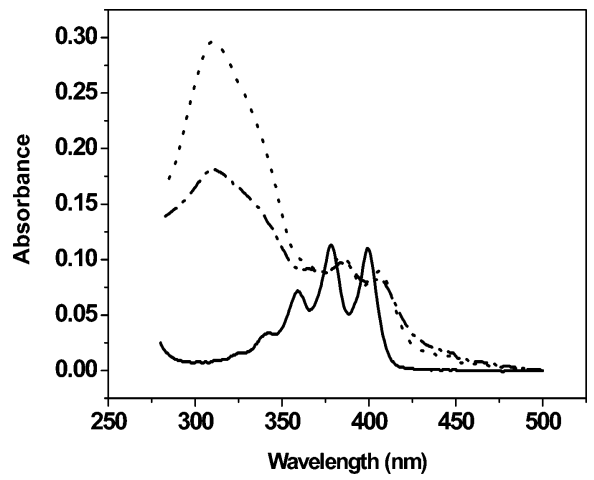

Figure 1. Absorption spectra of $\mathbf{2}$ (solid line, $\left.1 \times 10^{-5} \mathrm{M}\right), \mathbf{1 4}$ (dashdotted line, $7.4 \mathrm{mg} / \mathrm{L}$ ), and 15 (dotted line, $7.9 \mathrm{mg} / \mathrm{L}$ ) in $\mathrm{CH}_{2} \mathrm{Cl}_{2}$.

Copolymers $\mathbf{1 4}$ and $\mathbf{1 5}$ were synthesized by hydrosilylation of 12 and 13 with 2 in a similar manner as those described previously. ${ }^{6-9}$ It is noteworthy that the presence of a stoichiometric amount of sodium iodide was necessary in these hydrosilylation reactions. Presumably, the basic amine moiety may coordinate to the rhodium resulting in deactivation of the catalyst. Sodium ion may compete with the coordination site(s) of the azacrown ether moiety so that the rhodium catalyst may be released for the catalytic process. The ratios of the aminostyrene donor to anthracene chromophore in copolymers $\mathbf{1 4}$ and $\mathbf{1 5}$ were 2 to 1 . The parent amine $\mathbf{1 6}$ was synthesized similarly by the rhodium-catalyzed hydrosilylation of $\mathbf{1 7}$ with $\mathrm{Et}_{3} \mathrm{SiH}$.

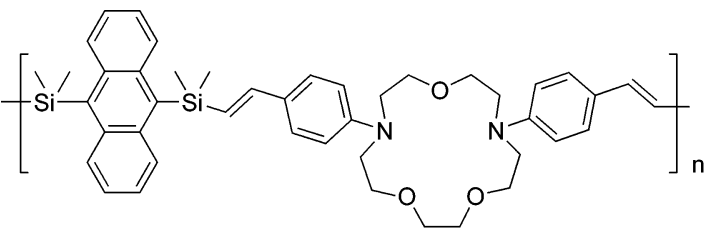

14

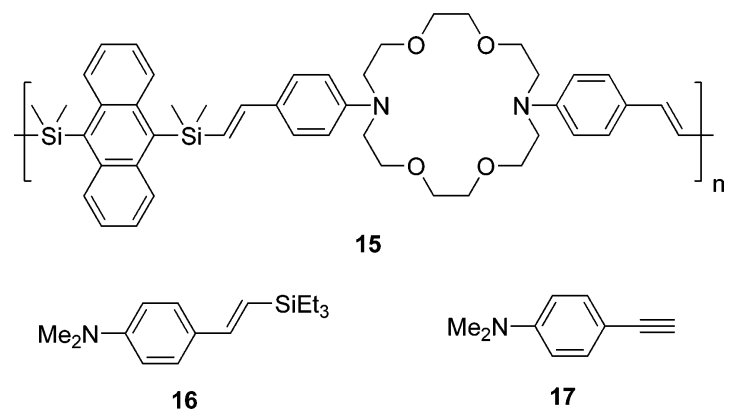

Photophysical Properties. Polymers 14 and 15 contain anthracene as the fluorophore and aminostyrene as the quencher. Using $\mathbf{2}$ and $\mathbf{1 6}$ as the model compounds, the photophysical and electrochemical properties (see Supporting Information) of these chromophores were examined, and the frontier orbital energies were thus estimated (Table 1).

The absorption and emission spectra of $\mathbf{2}$ and copolymers 14 and 15 in $\mathrm{CH}_{2} \mathrm{Cl}_{2}$ are shown in Figure 1. The absorption from 350 to $430 \mathrm{~nm}$ with vibronic fine structures was attributed to anthracene chromophore in $\mathbf{1 4}$ and $\mathbf{1 5}$, and the broad peak around $310 \mathrm{~nm}$ was assigned to the absorption of the aminostyrene moiety. It is striking to note that the relative absorbance at $310 \mathrm{~nm}$ for $\mathbf{1 4}$ and $\mathbf{1 5}$ are different. Presumably, the incorporation of different azacrown ether moieties in these copolymers might cause conformational change, resulting in discrepancy in extinction coefficients of the aminostyrene chromophores. Compound $\mathbf{2}$ showed emission maximum at 412 and $433 \mathrm{~nm}$ with the quantum yield 0.65. The emissions of 14 and 15 around $410 \mathrm{~nm}$ were very weak, and the corresponding quantum yields were 0.011 and 0.006 (Figure 2). These results suggested that photoinduced electron transfer between the aminostyrene group and the anthracene moiety might take place. Indeed, addition of metal cations such as $\mathrm{Cd}^{2+}$ or other cations (e.g., $\mathrm{Sr}^{2+}$ or $\mathrm{Ba}^{2+}$; see Supporting Information) showed significant enhancement of fluorescence intensity (Figure 3). This result supports the PET mechanism in these silylene-spaced copolymers $\mathbf{1 4}$ and $\mathbf{1 5}$.

Time-Resolved Fluorescence Spectroscopy. The fluorescence lifetime for the reference 2 was determined to be $14 \mathrm{~ns}$ by the time-correlated photon counting system (see Supporting Information). A femtosecond laser equipped with a streak camera was employed to measure the time-resolved spectra of fluorescence quenching in polymers $\mathbf{1 4}$ and $\mathbf{1 5}$ due to PET. The fluorescence decay profiles of 14 and 15 in $\mathrm{CHCl}_{3}$ and $\mathrm{CH}_{2} \mathrm{Cl}_{2}$ are shown in Figure 4. The fluorescence decay lifetimes $(\tau)$ were estimated by biexponential curve-fittings, and the results are 
Table 2. Fluorescence Lifetime $(\tau)$, Rate Constant $\left(k_{\mathrm{CS}}\right)$, and Yield $\left(\Phi_{\mathrm{CS}}\right)$ of 14 and 15 in $\mathrm{CHCl}_{3}$ and $\mathrm{CH}_{2} \mathrm{Cl}_{2}$ at $\mathrm{Ambient}$ Temperature

\begin{tabular}{|c|c|c|c|c|c|c|c|}
\hline \multirow[b]{2}{*}{ polymer $^{a}$} & \multirow[b]{2}{*}{ solvent } & \multicolumn{2}{|c|}{ fluorescence lifetime, ${ }^{b} \tau(\mathrm{ps})$} & \multicolumn{2}{|c|}{ charge-transfer rate, $k_{\mathrm{CS}}\left(\mathrm{ns}^{-1}\right)$} & \multicolumn{2}{|c|}{ charge-separation yield, $\Phi_{\mathrm{CS}}$} \\
\hline & & $\tau_{1}$ & $\tau_{2}$ & $k_{\mathrm{CS} 1}$ & $k_{\mathrm{CS} 2}$ & $\Phi_{\mathrm{CS} 1}$ & $\Phi_{\mathrm{CS} 2}$ \\
\hline \multirow[t]{2}{*}{14} & $\mathrm{CHCl}_{3}$ & $76(0.58)$ & $430(0.42)$ & 13.1 & 2.3 & 0.99 & 0.97 \\
\hline & $\mathrm{CH}_{2} \mathrm{Cl}_{2}$ & $31(0.69)$ & $225(0.31)$ & 32.2 & 4.4 & 0.99 & 0.98 \\
\hline \multirow[t]{2}{*}{15} & $\mathrm{CHCl}_{3}$ & $92(0.82)$ & $576(0.18)$ & 10.8 & 1.7 & 0.99 & 0.96 \\
\hline & $\mathrm{CH}_{2} \mathrm{Cl}_{2}$ & $47(0.88)$ & $404(0.12)$ & 21.2 & 2.4 & 0.99 & 0.97 \\
\hline $18^{c}$ & hexanol & \multicolumn{2}{|c|}{333} & \multicolumn{2}{|c|}{$2.9^{f}$} & \multicolumn{2}{|c|}{$0.97^{f}$} \\
\hline $1^{d}$ & $\mathrm{H}_{2} \mathrm{O}$ & \multicolumn{2}{|c|}{320} & \multicolumn{2}{|c|}{3.0} & \multicolumn{2}{|c|}{0.97} \\
\hline $20^{e}$ & $\mathrm{CH}_{3} \mathrm{CN}$ & \multicolumn{2}{|c|}{39} & \multicolumn{2}{|c|}{$25.2^{f}$} & \multicolumn{2}{|c|}{$0.98^{f}$} \\
\hline
\end{tabular}

${ }^{a}$ The concentrations $\left(\sim 10^{-5} \mathrm{M}\right)$ of $\mathbf{1 4}$ and $\mathbf{1 5}$ are determined by extinction coefficient, and 9,10-disilyl anthracene is used to be reference. ${ }^{b}$ Timeresolved fluorescence lifetimes are estimated by exponential fitting of decay curve $\left(R^{2}=0.98-0.99\right)$. The relative weights of different time constants are included in parentheses. ${ }^{c}$ From ref $19 .{ }^{d}$ From ref $20 .{ }^{e}$ From ref $21 .{ }^{f}$ Calculated values based on the corresponding literature data in refs $19-21$.

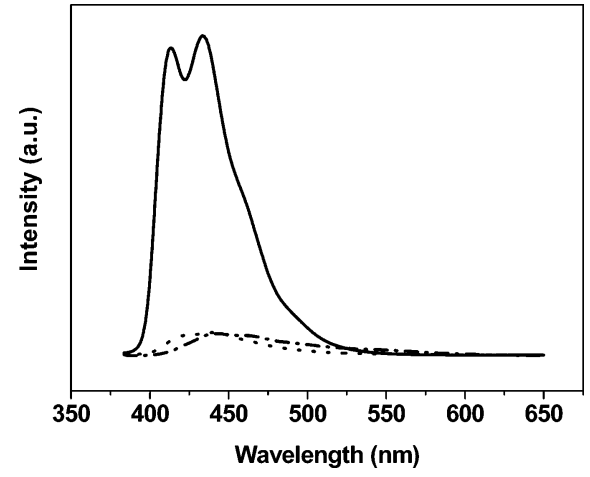

Figure 2. Fluorescence spectra of 2 (solid line, $1 \times 10^{-5} \mathrm{M}$ ), $\mathbf{1 4}$ (dashdotted line, $7.4 \mathrm{mg} / \mathrm{L}$ ), and $\mathbf{1 5}$ (dotted line, $7.9 \mathrm{mg} / \mathrm{L}$ ) in $\mathrm{CH}_{2} \mathrm{Cl}_{2} ; \lambda_{\mathrm{ex}}=$ $381 \mathrm{~nm}$.

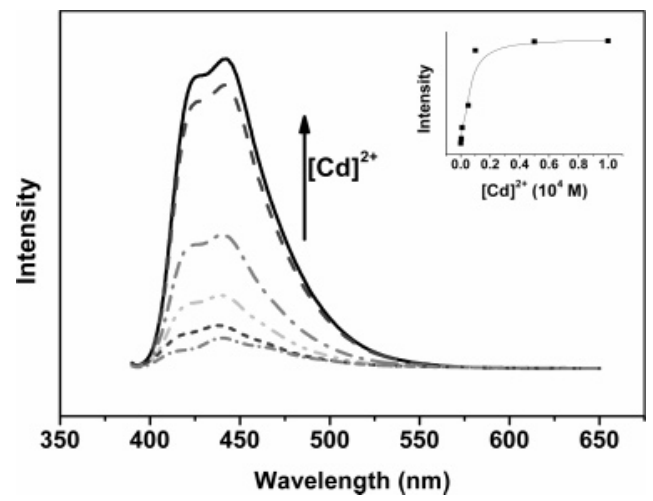

Figure 3. Fluorescence spectral changes of $14(7.4 \mathrm{mg} / \mathrm{L})$ upon increasing titration with $\mathrm{Cd}\left(\mathrm{ClO}_{4}\right)_{2}$ (excitation at $381 \mathrm{~nm}$ ) in $\mathrm{CH}_{2}$ $\mathrm{Cl}_{2}$. Inset: relative fluorescence intensity vs $\mathrm{Cd}^{2+}$ concentrations at $445 \mathrm{~nm}$.

summarized in Table 2. The charge-transfer rate constant $k_{\mathrm{CS}}$ and the corresponding charge-separation yield $\Phi_{\mathrm{CS}}$ were calculated according to eqs 1 and 2, ${ }^{18}$ in which the $k_{\mathrm{S}}$ was the reciprocal of the fluorescence lifetime of $2\left(0.07 \mathrm{~ns}^{-1}\right)$. As can be seen from Table 2, two different fluorescence lifetimes were obtained for each of copolymers 14 and $\mathbf{1 5}$. It is worthy to note that the lifetimes $(\tau)$ were shorter and the charge transfer rates $\left(k_{\mathrm{CS}}\right)$ were faster in $\mathrm{CH}_{2} \mathrm{Cl}_{2}$ than those in $\mathrm{CHCl}_{3}$.

$$
\begin{aligned}
& k_{\mathrm{CS}}=\tau^{-1}-k_{\mathrm{s}} \\
& \Phi_{\mathrm{CS}}=k_{\mathrm{CS}} / \tau^{-1}
\end{aligned}
$$

The presence of the geminal dimethyl group on silicon might dictate the relative conformation of the remaining substituents on this silicon atom. In other words, the Thorpe-Ingold effect ${ }^{22}$
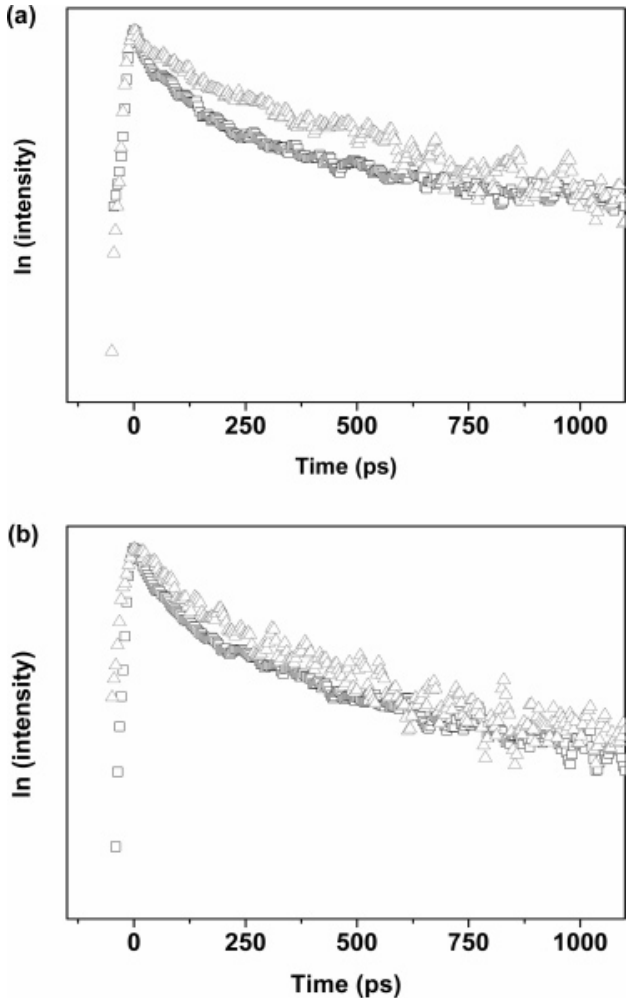

Figure 4. Time-resolved fluorescence decays of (a) 14 (7.4 mg/L) and (b) $15\left(7.9 \mathrm{mg} / \mathrm{L}\right.$ ) in $\mathrm{CHCl}_{3}$ (gray open triangle) and $\mathrm{CH}_{2} \mathrm{Cl}_{2}$ (black open square) with excitation at $395 \mathrm{~nm}$ and detection at $420-460 \mathrm{~nm}$.

due to the presence of such geminal dimethyl group would enable the aminostyrene group and the anthracene moiety in close proximity. Consequently, electron transfer between neighboring donor aminostyrene chromophore and acceptor anthracene moiety might be facile, leading to fast charge transfer rate $\left(k_{\mathrm{CS}} \sim 10.8-32.2 \mathrm{~ns}^{-1}\right)$.

It is known that conformational change may influence the rate of the intramolecular electron transfer. ${ }^{21,23}$ Because of different arrangements of the chromophores, dual electron transfer rates are occasionally obtained. The silylene-divinylarene copolymers are highly folded. ${ }^{6-8}$ Through-space interaction between two chromophore would therefore be feasible in these copolymers. Slower rates $\left(k_{\mathrm{CS}} \sim 1.7-\right.$ $4.4 \mathrm{~ns}^{-1}$ ) might be expected from the through-space electron transfer between nonneighboring donor aminostyrene chromophore and the acceptor anthracene moiety in $\mathbf{1 4}$ or 15.

Our results indicated that the charge separation of $\mathbf{1 4}$ and $\mathbf{1 5}$ are highly efficient in these silylene-spaced alternating donor- 
acceptor copolymers. In comparison with the charge separation efficiencies of other small molecules containing similar donor and acceptor moieties (e.g., 18-20, ${ }^{19-21}$ Table 2), similar efficiencies were obtained from copolymers $\mathbf{1 4}$ and $\mathbf{1 5}$.

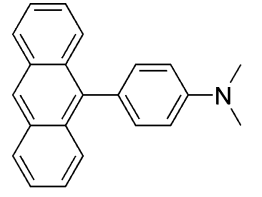

18

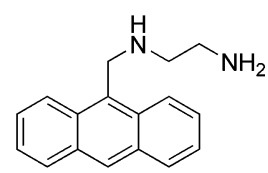

19

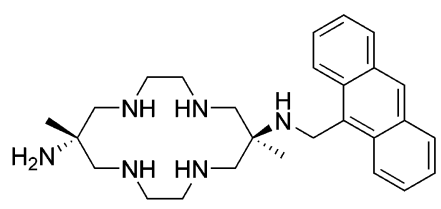

20

\section{Conclusions}

The silylene-spaced copolymers have been shown to exhibit a variety of fascinating photophysical properties because of conformational flexibility. ${ }^{6}$ The silylene moiety has provided an insulating spacer between two linking conjugated moieties. In addition, the presence of the geminal dimethyl substituents on silicon in these polymers may direct the relative conformation (or distance) of the remaining substituents on silicon so that interactions between these substituents may readily take place. In this study, we have demonstrated a new type of silylenespaced copolymer with alternating aminostyrene and anthracene moieties for efficient photoinduced electron transfer. These copolymers have been shown to exhibit efficient charge separation, and the relative rates for electron transfer are comparable to those in small molecules having similar chromophores. Preliminary examinations suggested that these azacrown ether-containing copolymers may serve as sensors selective for large divalent cations such as $\mathrm{Cd}^{2+}, \mathrm{Sr}^{2+}$, or $\mathrm{Ba}^{2+}$ cations. Further investigations are in progress in our laboratory.

\section{Experimental Section}

General. High-resolution mass was obtained from Jeol-JMS700 mass spectrometry using FAB method in 3-nitrobenzyl alcohol matrix. Gel permeation chromatography (GPC) was performed on a Waters GPC machine using an isocratic HPLC pump (1515) and a refractive index detector (2414). THF was used as the eluent (flow rate $=1 \mathrm{~mL} / \mathrm{min}$ ). Waters Styragel HR2, HR3, HR3, and HR4 $(7.8 \times 300 \mathrm{~mm})$ columns were employed for molecular weight determination, and polystyrenes were used as standard $\left(M_{\mathrm{n}}\right.$ values ranging from 375 to $3.5 \times 10^{6}$ ). Absorption spectra were measured with Hitachi U-3310 spectrophotometer and emission spectra with Hitachi F-4500 fluorescence spectrophotometer. Quantum yield was obtained using coumarin-I in EtOAc as reference $(\Phi=0.99)$. In time-resolved fluorescence experiments, a mode-locked Ti:sapphire laser (wavelength: $790 \mathrm{~nm}$; repetition rate: $76 \mathrm{MHz}$; pulse width: $<200 \mathrm{fs}$ ) passed through an optical parametric amplifier. The fluorescence of sample was reflected by a grating (150 grooves/ $\mathrm{mm}$; BLZ: $500 \mathrm{~nm}$ ) and detected by an optically triggered streak camera (Hamamatsu C5680) with a time resolution of about 0.3 ps.

9,10-Bis(dimethylsilyl)anthracene (2). A solution of $n$-butyllithium in hexane ( $18.0 \mathrm{~mL}$ of $2.5 \mathrm{M}$ solution, $45 \mathrm{mmol}$ ) was added dropwise to a suspension of 9,10-dibromoanthracene $(5.00 \mathrm{~g}$, $14.9 \mathrm{mmol})$ in $\mathrm{Et}_{2} \mathrm{O}(50 \mathrm{~mL})$ at $-78{ }^{\circ} \mathrm{C}$, and the mixture was stirred for $1 \mathrm{~h}$ at $-78{ }^{\circ} \mathrm{C}$. Chlorodimethylsilane (4.6 g, $49 \mathrm{mmol}$ ) was added dropwise to the solution at $-78^{\circ} \mathrm{C}$. The mixture was allowed to warm gradually to room temperature (rt) for $8 \mathrm{~h}$ and hydrolyzed with aqueous sodium hydrogen carbonate. The organic layer was extracted with ether and dried over anhydrous $\mathrm{MgSO}_{4}$. Recrystallization of eluted materials from ethanol gave 9,10-bis(dimethylsilyl)anthracene $(1.92 \mathrm{~g}, 44 \%)$ as pale yellow crystals; mp 96$99{ }^{\circ} \mathrm{C}$. IR (KBr): $v$ 3078, 3052, 2954, 2897, 2149, 1679, 1515, 1442, 1283, 1247, 1037, 961, 896, 829, 773, 739, 698, 686, 641, $605,578 \mathrm{~cm}^{-1} .{ }^{1} \mathrm{H}$ NMR $\left(400 \mathrm{MHz}, \mathrm{CDCl}_{3}\right): \delta 0.71(\mathrm{~d}, J=4.1$ $\mathrm{Hz}, 6 \mathrm{H}), 5.47$ (sep, $J=4.1 \mathrm{~Hz}, 1 \mathrm{H}), 7.49-7.52$ (m, $4 \mathrm{H}$ ), 8.578.59 (m, $4 \mathrm{H}) .{ }^{13} \mathrm{C} \mathrm{NMR}\left(\mathrm{CDCl}_{3}, 100 \mathrm{MHz}\right): \delta-1.4,124.6,129.3$, 136.2, 136.8. MS $\mathrm{m} / \mathrm{z}$ (rel intensity): $294\left(\mathrm{M}^{+}, 100\right), 293$ (13), 235 (37), 219 (9), 178 (7). HRMS (FAB) $\left(\mathrm{M}^{+}, \mathrm{C}_{18} \mathrm{H}_{22} \mathrm{Si}_{2}\right)$ : calcd 294.1260; found 294.1261.

$N$-(4-Iodophenyl)-2-\{2-[(4-iodophenylcarbamoyl)methoxy]ethoxy acetamide (4). To a solution of 4-iodoaniline (10.96 g, $50 \mathrm{mmol})$ and pyridine $(4.1 \mathrm{~mL})$ in THF $(30 \mathrm{~mL})$ was added dropwise a solution of diacid chloride 3 (4.9 g, $27 \mathrm{mmol}$ ) in THF $(20 \mathrm{~mL})$. The reaction mixture was stirred at room temperature for $2 \mathrm{~h}$. The solvent was removed by evaporation followed by addition of water into the residue. The precipitate was collected by filtration and washed with water to give a white solid (11.9 g, 82\%); mp $143-144{ }^{\circ} \mathrm{C}$. IR (KBr): $v$ 3386, 3111, 2912, 1683, 1588, 1532, 1487, 1395, 1104, 1056, $818 \mathrm{~cm}^{-1} .{ }^{1} \mathrm{H}$ NMR $\left(400 \mathrm{MHz}, \mathrm{CDCl}_{3}\right)$ : $\delta 3.86(\mathrm{~s}, 4 \mathrm{H}), 4.16(\mathrm{~s}, 4 \mathrm{H}), 7.28(\mathrm{~d}, J=8.6 \mathrm{~Hz}, 4 \mathrm{H}), 7.58(\mathrm{~d}$, $J=8.6 \mathrm{~Hz}, 4 \mathrm{H}), 8.34(\mathrm{~s}, 2 \mathrm{H}) .{ }^{13} \mathrm{C} \mathrm{NMR}\left(\mathrm{CDCl}_{3}, 100 \mathrm{MHz}\right): \delta$ $70.8,70.9,88.1,121.4,136.6,138.0,167.2$. MS $\mathrm{m} / \mathrm{z}$ (rel intensity): $581\left(\mathrm{M}^{+}+\mathrm{H}, 93\right), 537$ (2), 536 (1), 455 (4), 391 (9), 380 (2), 304 (29), 232 (8). HRMS (FAB) $\left(\mathrm{M}^{+}+\mathrm{H}, \mathrm{C}_{18} \mathrm{H}_{18} \mathrm{BrI}_{2} \mathrm{~N}_{2} \mathrm{O}_{4}\right)$ : calcd 580.9434; found 580.9427. Anal. Calcd for $\mathrm{C}_{18} \mathrm{H}_{18^{-}}$ $\mathrm{BrI}_{2} \mathrm{~N}_{2} \mathrm{O}_{4}$ : C, 37.26; H, 3.13. Found: C, 36.94; H, 3.23.

1,2-Bis $\{2$-[N-(4-iodophenylamino)]ethoxy $\}$ ethane (5). A $2 \mathrm{M}$ solution of $\mathrm{BH}_{3} \mathrm{SMe}_{2}$ complex $(25 \mathrm{~mL}, 50 \mathrm{mmol})$ was added dropwise to a solution of diamide $\mathbf{4}(5.8 \mathrm{~g}, 10 \mathrm{mmol})$ in anhydrous THF. The reaction mixture was refluxed under nitrogen for $16 \mathrm{~h}$. After cooling, the excess diborane was destroyed by dropwise addition of water followed by evaporation. Treatment of the residue with $\mathrm{CHCl}_{3}$, subsequent filtration, and condensation of filtrate gave a crude product, which was purified by column chromatography (4.7 g, 85\%); mp 58-59 ${ }^{\circ} \mathrm{C}$. IR (KBr): $v$ 3402, 3067, 3023, 2872, 2578, 1883, 1594, 1498, 1398, 1321, 1295, 1254, 1183, 1135, 1091, 996, $812 \mathrm{~cm}^{-1} .{ }^{1} \mathrm{H}$ NMR $\left(400 \mathrm{MHz}, \mathrm{CDCl}_{3}\right): \delta 3.26(\mathrm{t}, J=$ $5.1 \mathrm{~Hz}, 4 \mathrm{H}), 3.65(\mathrm{~s}, 4 \mathrm{H}), 3.69(\mathrm{t}, J=5.1 \mathrm{~Hz}, 4 \mathrm{H}), 4.00$ (bs, $2 \mathrm{H}), 6.40(\mathrm{~d}, J=8.5 \mathrm{~Hz}, 4 \mathrm{H}), 7.41(\mathrm{~d}, J=8.5 \mathrm{~Hz}, 4 \mathrm{H}) .{ }^{13} \mathrm{C}$ NMR $\left(\mathrm{CDCl}_{3}, 100 \mathrm{MHz}\right): \delta 43.3,69.4,70.2,78.2,115.2,137.7$, 147.7. MS m/z (rel intensity): $553\left(\mathrm{M}^{+}+\mathrm{H}, 75\right), 427$ (5), 391 (13), 371 (2), 246 (21), 232 (61), 181 (15). HRMS (FAB) $\left(\mathrm{M}^{+}+\mathrm{H}\right.$, $\mathrm{C}_{18} \mathrm{H}_{23} \mathrm{I}_{2} \mathrm{~N}_{2} \mathrm{O}_{2}$ ): calcd 552.9849; found 552.9838.

7,13-Bis(4-iodophenyl)-1,4,10-trioxa-7,13-diazacyclopentadecane-8,12-dione (6). Two separate solution of diamine 5 (3.60 g, $6.52 \mathrm{mmol})$, dry pyridine $(1.4 \mathrm{~mL})$ in dry toluene $(150 \mathrm{~mL})$, and the corresponding diacid dichloride $(1.11 \mathrm{~g}, 7.16 \mathrm{mmol})$ in toluene $(150 \mathrm{~mL})$ were placed in two dropping funnels. The two solutions were added simultaneously and dropwise to $300 \mathrm{~mL}$ of dry toluene stirred under a nitrogen atmosphere. After $12 \mathrm{~h}$ of stirring at room temperature, the mixture was filtered and the filtrate was evaporated. The residue was purified by column chromatograpy (silica gel with $\left.\mathrm{CHCl}_{3}\right)(2.88 \mathrm{~g}, 67.9 \%) ; \mathrm{mp} 211-212{ }^{\circ} \mathrm{C}$. IR (KBr): v 2910, 2850, $1670,1560,1458,1437,1412,1383,1352,1101,1005,874 \mathrm{~cm}^{-1}$. ${ }^{1} \mathrm{H}$ NMR $\left(500 \mathrm{MHz}, \mathrm{CDCl}_{3}, 333 \mathrm{~K}\right): \delta 3.46-3.50(\mathrm{~m}, 4 \mathrm{H}), 3.60$ (s, $4 \mathrm{H}), 3.83$ (br, $4 \mathrm{H}), 4.16$ (br, $4 \mathrm{H}), 7.07$ (d, $J=7.8 \mathrm{~Hz}, 4 \mathrm{H})$, $7.73(\mathrm{~d}, J=8.5 \mathrm{~Hz}, 4 \mathrm{H}) .{ }^{13} \mathrm{C}$ NMR $\left(\mathrm{CDCl}_{3}, 125 \mathrm{MHz}, 333 \mathrm{~K}\right)$ : $\delta 48.1,67.0,67.6,70.3,93.3,130.6,138.9,140.6,169.0 . \mathrm{MS} m / z$ (rel intensity): $651\left(\mathrm{M}^{+}+\mathrm{H}, 98\right), 650(5), 623$ (4), 318 (1), 273 (2), 195 (1), 165 (3). HRMS (FAB) $\left(\mathrm{M}^{+}+\mathrm{H}, \mathrm{C}_{22} \mathrm{H}_{25} \mathrm{I}_{2} \mathrm{~N}_{2} \mathrm{O}_{5}\right)$ : calcd 650.9853; found 650.9861. Anal. Calcd for $\mathrm{C}_{22} \mathrm{H}_{24} \mathrm{I}_{2} \mathrm{~N}_{2} \mathrm{O}_{5}$ : C, 40.64; H, 3.72. Found: C, 39.98; H, 3.73.

7,16-Bis(4-iodophenyl)-1,4,10,13-tetraoxa-7,16-diaza-cyclooctadecane-6,17-dione (7). Two separate solution of diamine $\mathbf{5}$ $(1.66 \mathrm{~g}, 3 \mathrm{mmol})$, dry pyridine $(0.7 \mathrm{~mL})$ in dry toluene $(65 \mathrm{~mL})$, and the corresponding diacid dichloride $3(0.7 \mathrm{~g}, 3.3 \mathrm{mmol})$ in toluene $(65 \mathrm{~mL})$ were placed in two dropping funnels. The two solutions were added simultaneously and dropwise to $130 \mathrm{~mL}$ of dry toluene stirred under a nitrogen atmosphere. After $12 \mathrm{~h}$ of 
stirring at room temperature, the mixture was filtered and the filtrate was evaporated. The residue was purified by column chromatograpy (silica gel with $\left.\mathrm{CHCl}_{3}\right)(1.54 \mathrm{~g}, 74 \%)$; mp $177-178{ }^{\circ} \mathrm{C}$. IR (KBr): v 3004, 2872, 1908, 1673, 1584, 1484, 1431, 1349, 1284, 1223, 1107, 1008, 898, 833, $753 \mathrm{~cm}^{-1} .{ }^{1} \mathrm{H}$ NMR (400 MHz, $\left.\mathrm{CDCl}_{3}\right): \delta$ $3.40-3.70(\mathrm{~m}, 12 \mathrm{H}), 3.85-4.00(\mathrm{~m}, 8 \mathrm{H}), 7.13(\mathrm{~d}, J=7.5 \mathrm{~Hz}$, $4 \mathrm{H}), 7.78$ (d, $J=7.5 \mathrm{~Hz}, 4 \mathrm{H}) .{ }^{13} \mathrm{C} \mathrm{NMR}\left(\mathrm{CDCl}_{3}, 100 \mathrm{MHz}\right): \delta$ 47.7, 67.2, 70.1, 70.4, 71.1, 93.9, 130.8, 138.9, 139.9, 168.9. MS $\mathrm{m} / \mathrm{z}$ (rel intensity): $695\left(\mathrm{M}^{+}+\mathrm{H}, 100\right), 667$ (5), 568 (2), 567 (1), 450 (2), 420 (1), 348 (7), 304 (4). HRMS (FAB) $\left(\mathrm{M}^{+}+\mathrm{H}\right.$, $\mathrm{C}_{24} \mathrm{H}_{29} \mathrm{I}_{2} \mathrm{~N}_{2} \mathrm{O}_{6}$ ): calcd 695.0115; found 695.0110. Anal. Calcd for $\mathrm{C}_{24} \mathrm{H}_{28} \mathrm{I}_{2} \mathrm{~N}_{2} \mathrm{O}_{6}$ : C, 41.52; H, 4.06. Found: C, 41.53; H, 4.15.

7,13-Bis(4-iodophenyl)-1,4,10-trioxa-7,13-diaza-cyclopentadecane (8). A $2 \mathrm{M}$ solution of $\mathrm{BH}_{3} \mathrm{SMe}_{2}$ complex $(5.22 \mathrm{~mL}$, $10.44 \mathrm{mmol}$ ) was added dropwise via a syringe to a solution of diamide 6 (1.32 g, $2.08 \mathrm{mmol})$ in anhydrous THF $(50 \mathrm{~mL})$. The reaction mixture was refluxed under nitrogen for $16 \mathrm{~h}$. After cooling, the excess diborane was destroyed by dropwise addition of water followed by evaporation. Treatment of the residue with $\mathrm{CHCl}_{3}$, subsequent filtration, and condensation of filtrate gave a crude product, which was purified by column chromatography (silica gel with $\left.\mathrm{CH}_{2} \mathrm{Cl}_{2}\right)(1.06 \mathrm{~g}, 82 \%)$; $\mathrm{mp} 140-142{ }^{\circ} \mathrm{C}$. IR (KBr): $v 2864$, $1585,1552,1491,1450,1383,1348,1127,870,805 \mathrm{~cm}^{-1} .{ }^{1} \mathrm{H}$ NMR $\left(400 \mathrm{MHz}, \mathrm{CDCl}_{3}\right): \delta 3.45-3.65(\mathrm{~m}, 16 \mathrm{H}), 3.70-3.76(\mathrm{~m}, 4 \mathrm{H})$, $6.47(\mathrm{~d}, J=8.8 \mathrm{~Hz}, 4 \mathrm{H}), 7.40(\mathrm{~d}, J=8.8 \mathrm{~Hz}, 4 \mathrm{H}) .{ }^{13} \mathrm{C} \mathrm{NMR}$ $\left(\mathrm{CDCl}_{3}, 100 \mathrm{MHz}\right): \delta 52.0,52.1,68.9,69.7,70.7,76.9,114.2$, 137.1, 147.2. MS $m / z$ (rel intensity): $623\left(\mathrm{M}^{+}+\mathrm{H}, 30\right), 622(6)$, 495 (3), 376 (3), 167 (3). HRMS (FAB) ( $\left.\mathrm{M}^{+}+\mathrm{H}, \mathrm{C}_{22} \mathrm{H}_{29} \mathrm{I}_{2} \mathrm{~N}_{2} \mathrm{O}_{3}\right)$ : calcd 623.0268; found 623.0276. Anal. Calcd for $\mathrm{C}_{22} \mathrm{H}_{28} \mathrm{I}_{2} \mathrm{~N}_{2} \mathrm{O}_{3}$ : C, 42.46; H, 4.54. Found: C, 42.45; H, 4.54.

7,16-Bis(4-iodophenyl)-1,4,10,13-tetraoxa-7,16-diazacyclooctadecane (9). A $2 \mathrm{M}$ solution of $\mathrm{BH}_{3} \mathrm{SMe}_{2}$ complex $(4.5 \mathrm{~mL}$, $9 \mathrm{mmol}$ ) was added dropwise via a syringe to a solution of diamide $7(1 \mathrm{~g}, 1.4 \mathrm{mmol})$ in anhydrous THF. The reaction mixture was refluxed under nitrogen for $16 \mathrm{~h}$. After cooling, the excess diborane was destroyed by dropwise addition of water followed by evaporation. Treatment of the residue with $\mathrm{CHCl}_{3}$, subsequent filtration, and condensation of filtrate gave a crude product, which was purified by column chromatography (silica gel with $\mathrm{CH}_{2} \mathrm{Cl}_{2}$ ) (0.66 g, 71\%); mp 133-134 ${ }^{\circ} \mathrm{C}$. IR (KBr): $v$ 3073, 2910, 2868, 1871, 1587, 1497, 1449, 1391, 1587, 1292, 1247, 1191, 1116, 927, $800 \mathrm{~cm}^{-1} .{ }^{1} \mathrm{H}$ NMR $\left(400 \mathrm{MHz}, \mathrm{CDCl}_{3}\right): \delta 3.55-3.70(\mathrm{~m}, 24 \mathrm{H})$, 6.46 (br d, $J=8.9 \mathrm{~Hz}, 4 \mathrm{H}), 7.43(\mathrm{~d}, J=8.9 \mathrm{~Hz}, 4 \mathrm{H}) .{ }^{13} \mathrm{C} \mathrm{NMR}$ $\left(\mathrm{CDCl}_{3}, 100 \mathrm{MHz}\right): \delta 51.3,68.8,70.9,114.1,137.8,147.3 . \mathrm{MS}$ $\mathrm{m} / \mathrm{z}$ (rel intensity): $667\left(\mathrm{M}^{+}+\mathrm{H}, 18\right), 623$ (1), 541 (2), 494 (2), 425 (4), 392 (5), 371 (1), 156 (5). HRMS (FAB) $\left(\mathrm{M}^{+}+\mathrm{H}\right.$, $\mathrm{C}_{24} \mathrm{H}_{33} \mathrm{I}_{2} \mathrm{~N}_{2} \mathrm{O}_{4}$ ): calcd 667.0530; found 667.0524. Anal. Calcd for $\mathrm{C}_{24} \mathrm{H}_{32} \mathrm{I}_{2} \mathrm{~N}_{2} \mathrm{O}_{4}$ : C, 43.26; H, 4.84. Found: C, 43.83; H, 4.98.

7,13-Bis $\{4-[($ trimethylsilyl)ethynyl $]$ phenyl $\}-1,4,10$-trioxa-7,13-diazacyclopentadecane (10). A mixture of $8(2.30 \mathrm{~g}$, $3.70 \mathrm{mmol})$, trimethylsilylacetylene $(2.24 \mathrm{~mL}, 11.1 \mathrm{mmol})$, Pd$\left(\mathrm{PPh}_{3}\right)_{2} \mathrm{Cl}_{2}$ (49.8 mg, $\left.0.07 \mathrm{mmol}\right), \mathrm{CuI}(7 \mathrm{mg}, 0.07 \mathrm{mmol})$ in $\mathrm{Et}_{3} \mathrm{~N}$ $(60 \mathrm{~mL})$, and THF $(30 \mathrm{~mL})$ was refluxed under nitrogen for $8 \mathrm{~h}$ and then cooled to room temperature. The mixture was filtered and $\mathrm{Et}_{3} \mathrm{~N}$ was evaporated. The crude product was purified by column chromatography (silica gel with $\mathrm{CH}_{2} \mathrm{Cl}_{2}$ and then $\mathrm{CHCl}_{3}$ ) (1.46 g, 70\%); $\mathrm{mp} 149-150{ }^{\circ} \mathrm{C}$. IR (KBr): v 2954, 2880, 2148, 1605, 1515, $1458,1389,1351,1248,1185,1128,864,837 \mathrm{~cm}^{-1} .{ }^{1} \mathrm{H}$ NMR $\left(400 \mathrm{MHz}, \mathrm{CDCl}_{3}\right): \delta 0.23(\mathrm{~s}, 18 \mathrm{H}), 3.52-3.64(\mathrm{~m}, 16 \mathrm{H}), 3.70-$ $3.76(\mathrm{~m}, 4 \mathrm{H}), 6.57(\mathrm{~d}, J=8.7 \mathrm{~Hz}, 4 \mathrm{H}), 7.29(\mathrm{~d}, J=8.7 \mathrm{~Hz}$, $4 \mathrm{H}) .{ }^{13} \mathrm{C} \mathrm{NMR}\left(\mathrm{CDCl}_{3}, 100 \mathrm{MHz}\right): \delta 0.2,51.7,51.9,68.7,70.0$, $70.8,91.2,106.3,109.8,111.5,133.2,148.1$. MS $\mathrm{m} / \mathrm{z}$ (rel intensity): $563\left(\mathrm{M}^{+}+\mathrm{H}, 100\right), 562(50), 531$ (5), 517 (6), 487 (4), 473 (5), 429 (5), 303 (4), 273 (8), 258 (6), 246 (11), 216 (10), 200 (9), 176 (9), 120 (2). HRMS (FAB) $\left(\mathrm{M}^{+}+\mathrm{H}, \mathrm{C}_{32} \mathrm{H}_{47} \mathrm{~N}_{2} \mathrm{O}_{3^{-}}\right.$ $\mathrm{Si}_{2}$ ): calcd 563.3125; found 563.3129. Anal. Calcd for $\mathrm{C}_{32} \mathrm{H}_{46} \mathrm{~N}_{2} \mathrm{O}_{3-}$ $\mathrm{Si}_{2}$ : C, 68.28; H, 8.24. Found: C, 67.99; H, 8.24.

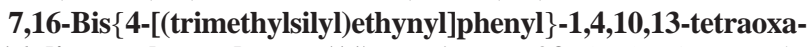
7,16-diazacyclooctadecane (11). A mixture of 9 (1.75 g, $2.6 \mathrm{mmol})$, trimethylsilylacetylene $(1.6 \mathrm{~mL}, 7.8 \mathrm{mmol}), \mathrm{Pd}\left(\mathrm{PPh}_{3}\right)_{2} \mathrm{Cl}_{2}(35 \mathrm{mg}$, $0.05 \mathrm{mmol}), \mathrm{CuI}(5 \mathrm{mg}, 0.05 \mathrm{mmol})$ in $\mathrm{Et}_{3} \mathrm{~N}(40 \mathrm{~mL})$, and THF
$(20 \mathrm{~mL})$ was refluxed under nitrogen for $8 \mathrm{~h}$ and then cooled to room temperature. The mixture was filtered and $\mathrm{Et}_{3} \mathrm{~N}$ was evaporated. The crude product was purified by column chromatography (silica gel with $\mathrm{CH}_{2} \mathrm{Cl}_{2}$ and then $\mathrm{CHCl}_{3}$ ) (1.15 g, 73\%); mp 116$117{ }^{\circ} \mathrm{C}$. IR ( $\left.\mathrm{KBr}\right): v 3104,3048,2960,2893,2150,1607,1517$, $1394,1356,1249,1190,1118,988,865,759 \mathrm{~cm}^{-1}$. ${ }^{1} \mathrm{H}$ NMR $\left(400 \mathrm{MHz}, \mathrm{CDCl}_{3}\right): \delta 0.22(\mathrm{~s}, 18 \mathrm{H}), 3.55-3.70(\mathrm{~m}, 24 \mathrm{H}), 6.55$ (br d, $J=8.5 \mathrm{~Hz}, 4 \mathrm{H}), 7.30(\mathrm{~d}, J=8.5 \mathrm{~Hz}, 4 \mathrm{H}) .{ }^{13} \mathrm{C} \mathrm{NMR}$ $\left(\mathrm{CDCl}_{3}, 100 \mathrm{MHz}\right): \delta 0.2,51.1,68.9,70.9,91.2,106.3,109.7$, 111.0, 133.3, 147.8. MS m/z (rel intensity): $606\left(\mathrm{M}^{+}, 100\right), 605$ (30), 511 (5), 510 (3), 330 (1), 316 (7), 290 (16), 228 (17), 216 (21), 186 (18), 158 (4), 136 (3). HRMS (FAB) $\left(\mathrm{M}^{+}, \mathrm{C}_{34} \mathrm{H}_{50} \mathrm{~N}_{2} \mathrm{O}_{4^{-}}\right.$ $\mathrm{Si}_{2}$ ): calcd 606.3309; found 606.3320. Anal. Calcd for $\mathrm{C}_{34} \mathrm{H}_{50} \mathrm{~N}_{2} \mathrm{O}_{4}$ $\mathrm{Si}_{2}$ : C, 67.28; H, 8.30. Found: C, 66.59; H, 8.28.

7,13-Bis(4-ethynylphenyl)-1,4,10-trioxa-7,13-diazacyclopentadecane (12). A mixture of $\mathbf{1 0}(1.38 \mathrm{~g}, 2.45 \mathrm{mmol})$ and $\mathrm{NaOH}$ $(0.20 \mathrm{~g}, 4.9 \mathrm{mmol})$ in $\mathrm{MeOH}(50 \mathrm{~mL})$ and $\mathrm{THF}(50 \mathrm{~mL})$ was stirred at room temperature for $1 \mathrm{~h}$. After filtration, the solvent was evaporated in vacuo. The residue was purified by column chromatography (silica gel with $\left.\mathrm{CH}_{2} \mathrm{Cl}_{2}\right)(0.92 \mathrm{~g}, 90 \%)$; mp $94-96{ }^{\circ} \mathrm{C}$. IR (KBr): $v 3287,3045,2876,2097,1606,1515,1449,1393,1351$, $1286,1180,1127,817 \mathrm{~cm}^{-1} .{ }^{1} \mathrm{H}$ NMR $\left(400 \mathrm{MHz}, \mathrm{CDCl}_{3}\right): \delta 2.98$ $(\mathrm{s}, 2 \mathrm{H}), 3.55-3.64(\mathrm{~m}, 16 \mathrm{H}), 3.74-3.77(\mathrm{~m}, 4 \mathrm{H}), 6.60(\mathrm{~d}, J=$ $8.2 \mathrm{~Hz}, 4 \mathrm{H}), 7.31(\mathrm{~d}, J=8.2 \mathrm{~Hz}, 4 \mathrm{H}) \cdot{ }^{13} \mathrm{C} \mathrm{NMR}\left(\mathrm{CDCl}_{3}\right.$, $100 \mathrm{MHz}): \delta 51.9,52.1,68.8,70.0,70.8,74.8,84.6,108.5,111.4$, 132.8, 147.8. MS $\mathrm{m} / \mathrm{z}$ (rel intensity): $418\left(\mathrm{M}^{+}, 100\right), 417$ (28), 387 (10), 370 (5), 289 (4), 242 (47), 200 (6), 174 (20), 144 (28), 115 (19). HRMS (FAB) $\left(\mathrm{M}^{+}, \mathrm{C}_{26} \mathrm{H}_{31} \mathrm{~N}_{2} \mathrm{O}_{3}\right)$ : calcd 418.2256; found 418.2247.

7,16-Bis(4-ethynylphenyl)-1,4,10,13-tetraoxa-7,16-diazacyclooctadecane (13). A mixture of $11(60.6 \mathrm{mg}, 0.1 \mathrm{mmol})$ and $\mathrm{NaOH}(8 \mathrm{mg}, 0.2 \mathrm{mmol})$ in $\mathrm{MeOH}(10 \mathrm{~mL})$ and THF $(10 \mathrm{~mL})$ was stirred at room temperature for $1 \mathrm{~h}$. After filtration, the solvent was evaporated in vacuo. The residue was purified by column chromatography (silica gel with $\mathrm{CH}_{2} \mathrm{Cl}_{2}$ ) (42 mg, 90\%); mp 108$110{ }^{\circ} \mathrm{C}$. IR (KBr): $v 3291,3098,3048,2873,2100,1896,1608$, $1517,1456,1394,1281,1355,1234,1185,1116,1000,818$, $756 \mathrm{~cm}^{-1} .{ }^{1} \mathrm{H}$ NMR $\left(400 \mathrm{MHz}, \mathrm{CDCl}_{3}\right): \delta 2.97(\mathrm{~s}, 2 \mathrm{H}), 3.60-$ $3.72(\mathrm{~m}, 24 \mathrm{H}), 6.57(\mathrm{~d}, J=8.7 \mathrm{~Hz}, 4 \mathrm{H}), 7.32(\mathrm{~d}, J=8.7 \mathrm{~Hz}, 4$ $\mathrm{H}) .{ }^{13} \mathrm{C} \mathrm{NMR}\left(\mathrm{CDCl}_{3}, 100 \mathrm{MHz}\right): \delta 51.1,68.9,71.0,74.8,84.7$, 108.5, 111.1, 133.4, 148.0. MS $\mathrm{m} / \mathrm{z}$ (rel intensity): $462\left(\mathrm{M}^{+}, 100\right)$,439 (10), 387 (6), 340 (7), 326 (6), 280 (6), 244 (14), 218 (26), 170 (26), 144 (47), 130 (37). HRMS (FAB) $\left(\mathrm{M}^{+}, \mathrm{C}_{28} \mathrm{H}_{34} \mathrm{~N}_{2} \mathrm{O}_{4}\right)$ : calcd 462.2519; found 462.2530 .

Polymer 14. Under nitrogen, a mixture of $12(0.125 \mathrm{~g}$, $0.3 \mathrm{mmol}), 2$ (0.087 g, $0.3 \mathrm{mmol}), \mathrm{NaI}(96 \mathrm{mg})$, and $\mathrm{Rh}\left(\mathrm{PPh}_{3}\right)_{3} \mathrm{Cl}$ $(15 \mathrm{mg})$ in THF $(5 \mathrm{~mL})$ was refluxed for $8 \mathrm{~h}$. After cooling to rt, the mixture was poured into $\mathrm{MeOH}$. The precipitate was collected and dissolved in THF and then reprecipitated with $\mathrm{MeOH}$. The product 1a was collected by filtration and washed with $\mathrm{MeOH}$ : $M_{\mathrm{n}}=6654, \mathrm{PDI}=1.4 \cdot{ }^{24} \mathrm{IR}(\mathrm{KBr}): v 3960,2867,1603,1516$, 1384, 1350, 1252, 1184, 1120, $814 \mathrm{~cm}^{-1}$. ${ }^{1} \mathrm{H}$ NMR $(400 \mathrm{MHz}$, $\left.\mathrm{CDCl}_{3}\right): \delta 0.7-0.8(\mathrm{~m}, 12 \mathrm{H}), 3.4-3.8(\mathrm{~m}, 20 \mathrm{H}), 6.6-6.7$ $(\mathrm{m}, 6 \mathrm{H}), 6.9-7.0(\mathrm{~m}, 2 \mathrm{H}), 7.2-7.4(\mathrm{~m}, 8 \mathrm{H}), 8.5-8.6(\mathrm{~m}, 4 \mathrm{H})$.

Polymer 15. Under nitrogen, a mixture of $13(138.7 \mathrm{mg}$, $0.3 \mathrm{mmol}), 2$ ( $87.6 \mathrm{mg}, 0.3 \mathrm{mmol}), \mathrm{NaI}(96 \mathrm{mg})$, and $\mathrm{Rh}\left(\mathrm{PPh}_{3}\right)_{3} \mathrm{Cl}$ $(15 \mathrm{mg})$ in THF $(5 \mathrm{~mL})$ was refluxed for $8 \mathrm{~h}$. After cooling to rt, the mixture was poured into $\mathrm{MeOH}$. The precipitate was collected and dissolved in THF and then reprecipitated with $\mathrm{MeOH}$. The product 1b was collected by filtration and washed with $\mathrm{MeOH}$ : $M_{\mathrm{n}}=7942, \mathrm{PDI}=2.7 .{ }^{24} \mathrm{IR}(\mathrm{KBr}): v 3085,3045,2946,2868$, $1604,1515,1385,1350,1264,1186,1114,812,736 \mathrm{~cm}^{-1} .{ }^{1} \mathrm{H}$ NMR $\left(400 \mathrm{MHz}, \mathrm{CDCl}_{3}\right): \delta 0.7-0.8(\mathrm{~m}, 12 \mathrm{H}), 3.4-3.9(\mathrm{~m}, 24 \mathrm{H})$, 6.6-6.7 (m, $6 \mathrm{H}), 6.9-7.0(\mathrm{~m}, 2 \mathrm{H}), 7.2-7.6(\mathrm{~m}, 8 \mathrm{H}), 8.5-8.6$ (m, $4 \mathrm{H})$.

$(E)-N, N$-Dimethyl-4-[2-(triethylsilyl)vinyl]aniline (16). Under a nitrogen atmosphere, a THF solution $(15 \mathrm{~mL})$ of $17(174 \mathrm{mg}$, $1.2 \mathrm{mmol}), \mathrm{Et}_{3} \mathrm{SiH}$ (140 mg, $\left.1.2 \mathrm{mmol}\right), \mathrm{NaI}(192 \mathrm{mg}, 1.2 \mathrm{mmol})$, and $\mathrm{RhCl}\left(\mathrm{PPh}_{3}\right)_{3}(55 \mathrm{mg}, 0.06 \mathrm{mmol})$ was refluxed for $4 \mathrm{~h}$. After cooled to $\mathrm{rt}$, the solvent was removed in vacuo, and the residue was chromatographed on silica gel (hexane) to give $\mathbf{1 6}$ as oil 
(106 mg, 34\%). IR (KBr): v 3014, 2951, 2908, 2873, 1602, 1519 , 1354, 1232, 1181, 1013, 824, 789, $726 \mathrm{~cm}^{-1} .{ }^{1} \mathrm{H}$ NMR $(400 \mathrm{MHz}$, $\left.\mathrm{CDCl}_{3}\right): \delta 0.69(\mathrm{q}, J=7.9 \mathrm{~Hz}, 6 \mathrm{H}), 1.03(\mathrm{t}, J=7.9 \mathrm{~Hz}, 9 \mathrm{H})$, $2.99(\mathrm{~s}, 6 \mathrm{H}), 6.20(\mathrm{~d}, J=19.3 \mathrm{~Hz}, 1 \mathrm{H}), 6.72(\mathrm{~d}, J=8.6 \mathrm{~Hz}$, $2 \mathrm{H}), 6.86(\mathrm{~d}, J=19.3 \mathrm{~Hz}, 1 \mathrm{H}), 7.38(\mathrm{~d}, J=8.6 \mathrm{~Hz}, 2 \mathrm{H}) .{ }^{13} \mathrm{C}$ $\mathrm{NMR}\left(\mathrm{CDCl}_{3}, 100 \mathrm{MHz}\right): \delta 3.6,7.4,40.5,112.2,120.0,127.28$, 127.32, 144.7, 150.3. MS m/z (rel intensity): 261 (100), 260 (36), 232 (21), 204 (3), 134 (4), 115 (7). HRMS (FAB) $\left(\mathrm{M}^{+}, \mathrm{C}_{16} \mathrm{H}_{27-}\right.$ NsSi): calcd 261.1913; found 261.1920.

Acknowledgment. This work was supported by the National Science Council, Academia Sinica, and National Taiwan University of the Republic of China.

Supporting Information Available: ${ }^{1} \mathrm{H}$ NMR spectra of all new compounds, influences of cations on the photophysical properties of 15, and electrochemical properties of $\mathbf{2}$ and 16. This material is available free of charge via the Internet at http:// pubs.acs.org.

\section{References and Notes}

(1) For reviews, see: (a) Wasielewski, M. R. Chem. Rev. 1992, 92, 435 (b) Gust, D.; Moore, T. A.; Moore, A. L. Acc. Chem. Res. 2001, 34 40. (c) Guldi, D. M. Chem. Soc. Rev. 2002, 31, 22. (d) Guldi, D. M.; Imahori, H. J. Porphyrins Phthalocyanines 2004, 8, 976. (e) Imahori, H. J. Phys. Chem. B 2004, 108, 6130. (f) Imahori, H. Org. Biomol. Chem. 2004, 2, 1425. (g) El-Khously, M. E.; Ito, O.; Smith, P. M.; D'Souza, F. J. Photochem. Photobiol. C 2004, 5, 79. (h) D'Souza, F.; Ito, O. Coord. Chem. Rev. 2005, 249, 1410. (i) Wasielewski, M. R. J. Org. Chem. 2006, 71, 5051.

(2) (a) D'Souza, F.; Smith, P. M.; Zandler, M. E.; McCarty, A. L.; Itou, M.; Araki, Y.; Ito, O. J. Am. Chem. Soc. 2004, 126, 7898. (b) Kercher, M.; Konig, B.; Zieg, H.; De Cola, L. J. Am. Chem. Soc. 2002, 124, 11541. (c) van Walree, C. A.; Roest, M. R. P.; Schuddeboom, W.; Jenneskens, L. W. Verhoeven, J. W.; Warman, J. M.; Kooijman, H.; Spek, A. L. J. Am. Chem. Soc. 1996, 118, 8395. For reviews, see: (d) Kaschak, D. M.; Johnson, S. A.; Waraksa, C. C.; Poque, J.; Mallouk, T. E. Coord. Chem. Res. 1999, 185-186, 403. (e) Dürr, H.; Bossmann, S. Acc. Chem. Res. 2001, 34, 905.

(3) (a) Kyushin, S.; Ikarugi, M.; Goto, M.; Hiratsuka, H.; Matsumoto, H. Organometallics 1996, 15, 1067. (b) Kwak, G.; Masuda, T. Macromolecules 2002, 35, 4138. (c) Duerr, B. F.; Chung, Y. S.; Czarnik, A. W. J. Org. Chem. 1988, 53, 2120. (d) Suzuki, H.; Satoh, S.; Kimata, Y.; Kuriyama, A. Chem. Lett. 1995, 451.

(4) (a) Li, W.-S.; Kim, K. S.; Jiang, D.-L.; Tanaka, H.; Kawai, T.; Kwon, J. H.; Kim, D.; Aida, T. J. Am. Chem. Soc. 2006, 128, 10527. (b) Nantalaksakul, A.; Reddy, D. R.; Bardeen, C. J.; Thayumanavan, S. Photosynthesis Res. 2006, 87, 133.

(5) (a) Fox, M. A. Acc. Chem. Res. 1992, 25, 569. (b) Webber. S. E. Chem. Rev. 1990, 90, 1469. (c) Nowakowska, M.; Foyle, P. V.; Guillet J. E. J. Am. Chem. Soc. 1993, 115, 5975. (d) Hisada, K.; Ito, S.; Yamamoto, M. Langmuir 1995, 11, 996. (e) Schultze, X.; Serin, J.; Adronov, A.; Frechet, J. M. J. Chem. Commun. 2001, 1160. (f) Russell, D. M.; Arias, A. C.; Friend, R. H.; Silvia, C.; Ego, C.; Grimsdale, A. C.; Mullen, K. Appl. Phys. Lett. 2002, 80, 2204.

(6) For a review, see: Luh, T.-Y.; Cheng, Y.-J. Chem. Commun. 2006, 4669.

(7) (a) Cheng, Y.-J.; Hwu, T.-Y.; Hsu, J.-H.; Luh, T.-Y. Chem. Commun 2002, 1978. (b) Cheng, Y. J.; Luh, T. Y. Chem.-Eur. J. 2004, 10, 5361. (c) Cheng, Y. J.; Luh, T. Y. Macromolecules 2005, 38, 4563.

(8) (a) Chen, R. M.; Chien, K. M.; Wong, K. T.; Jin, B. Y.; Luh, T.-Y. J. Am. Chem. Soc. 1997, 119, 11321. (b) Hwu, T. Y.; Basu, S.; Chen,
R. M.; Cheng, Y. J.; Hsu, J. H.; Fann, W.; Luh, T. Y. J. Polym. Sci., Part A: Polym. Chem. 2003, 40, 2218. (c) Cheng, Y. J.; Basu, S.; Luo, S. J.; Luh, T. Y. Macromolecules 2005, 38, 1442.

(9) Cheng, Y.-J.; Liang, H.; Luh, T.-Y. Macromolecules 2003, 36, 5912.

(10) Fang, M.-C.; Watanabe, A.; Matsuda, M. Macromolecules 1996, 29 6807.

(11) (a) Gokel, G. W. Crown Ethers and Cryptands; Royal Society of Chemistry: Cambridge, 1994. (b) Vögtle, F. Supramolecular Chemistry; Wiley: Chichester, 1991.

(12) For reviews, see: (a) de Silva, A. P.; Gunaratne, H. Q. N. Gunnlaugsson, T.; Huxley, A. J. M.; McCoy, C. P.; Rademacher, J. T.; Rice, T. E. Chem. Rev. 1997, 97, 1515. (b) Valeur, B.; Leray, I. Coord. Chem. Rev. 2000, 205, 3. (c) de Silva, A. P.; Fox, D. B.; Huxley, A. J. M.; Moody, T. S. Coord. Chem. Rev. 2000, 205, 41. (d) Gokel, G. W.; Leevy, W. M.; Weber, M. E. Chem. Rev. 2004, $104,2723$.

(13) (a) Minta, A.; Tsien, R. Y. J. Biol. Chem. 1989, 264, 19449. (b) Harootunian, A. T.; Kao, J. P. Y.; Eckert, B. K.; Tsien, R. Y. J. Biol. Chem. 1989, 264, 19458. (c) de Silva, A. P.; Gunaratne, H. Q. N.; Gunnlaugsson, T. Chem. Commun. 1996, 16, 1967. (d) Nishida, H.; Katayama, Y.; Katsuki, H.; Nakamura, H.; Tagaki, M.; Ueno, K. Chem. Lett. 1982, 1853. (e) Pearson, A. J.; Xiao, W. J. Org. Chem. 2003 68, 5361, 5369. (f) Su, N.; Bradshaw, J. S.; Zhang, X. X.; Song, H.; Savage, P. B.; Xue, G.; Krakowiak, K. E.; Izatt, R. M. J. Org. Chem. 1999, 64, 8855.

(14) (a) Lewis, F. D.; Burch, E. J. Am. Chem. Soc. 1994, 116, 1159. (b) Lawson, G.; Kitaygorodskiy, A.; Sun, Y. P. J. Org. Chem. 1999, 64, 5913. (c) Pischel, U.; Zhang, X.; Hellrung, B.; Haselbach, E.; Muller, P. A.; Nau, W. M. J. Am. Chem. Soc. 2000, 122, 2027. (d) Lor, M.; Thielemans, J.; Viaene, L.; Cotlet, M.; Hofkens, J.; Weil, T.; Hampel, C.; Müllen, K.; Verhoevne, J. W.; Van der Auweraer, M.; De Schryver, F. C. J. Am. Chem. Soc. 2002, 1124, 9918. (e) Dirksen, A.; Hahn, U.; Schwanke. F.; Nieger, M.; Reek, J. N. H.; Vögtle, F.; De Cola, L. Chem.-Eur. J. 2004, 10, 2036

(15) (a) Huston, M. E.; Haider, K. W.; Czarnik, A. W. J. Am. Chem. Soc. 1988, 110, 4460. (b) Fages, F.; Desvergne, J.-P.; Kampke, K.; BouasLaurent, H.; Lehn, J. P. M.; Meyer, M.; Albrecht-Gary, A. M. J. Am. Chem. Soc. 1993, 115, 3658. (c) Fabbrizzi, L.; Licchelli, M.; Pallavicini, P.; Taglietti, A. Inorg. Chem. 1996, 35, 1733. (d) Ojida, A.; Mito-oka, Y.; Inoue, M.; Hamachi, I. J. Am. Chem. Soc. 2002, 124, 6256. (e) Gunnlaugsson, T.; Ali, H. D. P.; Glynn, M.; Kruger, P. E.; Hussey, G. M.; Pfeffer, F. M.; dos Santos, C. M. G.; Tierney, J. J. Fluoresc. 2005, 15, 287.

(16) Kyushin, S.; Ikarugi, M.; Goto, M.; Hiratsuka, H.; Matsumoto, H. Organometallics 1996, 15, 1067.

(17) Ghorbanian, S.; Mehta, L. K.; Parrick, J.; Robson, C. H. Tetrahedron 1999, 55, 14467.

(18) (a) Sandanayaka, A. S. D.; Taguri, Y.; Araki, Y.; Ishi-i, T.; Mataka, S.; Ito, O. J. Phys. Chem. B 2005, 109, 22502. (b) Hattori, S.; Ohkubo, K.; Urano, Y.; Sunahara, H.; Nagano, T.; Wada, Y.; Tkachenko, N. V.; Lemmetyinen, H.; Fukuzumi, S. J. Phys. Chem. B 2005, 109, 15368 .

(19) Wiessner, A.; Hüttmann, G.; Kühnle, W.; Staerk, H. J. Phys. Chem. 1995, 99, 14923.

(20) Greiner, G.; Maier, I. J. Chem. Soc., Perkin Trans. 2002, 2, 1005

(21) Moore, E. G.; Bernhardt, P. V.; Fürstenberg, A.; Riley, M. J.; Smith, T. A.; Vauthey, E. J. Phys. Chem. A 2005, 109, 3788.

(22) Jung, M. E.; Piizzi, G. Chem. Rev. 2005, 105, 1735.

(23) D'Souza, F.; Chitta, R.; Gadde, S.; Shafiqul Islam, D.-M.; Schumacher, A. L.; Zandler, M. E.; Araki, Y.; Ito, O. J. Phys. Chem. B 2006, 110, 25240 .

(24) Attempts to obtain copolymers $\mathbf{1 4}$ or $\mathbf{1 5}$ with higher molecular weights under various conditions (amount of the Wilkinson catalyst, solvent, temperature, etc.) were unsuccessful.

MA070119T 